\title{
引張力を受ける積層ゴムの復元力特性に関する研究 MECHANICAL CHARACTERISTICS OF ELASTOMERIC SEISMIC ISOLATION BEARINGS UNDER TENSION
}

\author{
菊地 優*1, 北村 佳 久*2, 林 章二*3, 河島 庸一*4. \\ 坂口達*4, 山田親文*4 \\ Masaru KIKUCHI, Yoshihisa KITAMURA, Shoji HAYASHI, \\ Yoichi KAWASHIMA, Toru SAKAGUCHI and Chikafumi YAMADA
}

\begin{abstract}
This paper describes the vertical behavior of elastomeric isolation bearings. A study consists of three phases. In the first phase, dynamic loading tests are conducted. Two types of high-damping rubber bearings which differ in thickness of flange-plates are used. Second, finite element analyses are performed to simulate the test results. Both the tests and the analysis results show that the flangeplates has significant effect on tension modulus. Third, a hysteresis model is proposed. Good agreement between the experimental and the analysis results shows that the model can be an effective numerical tool to predict the seismic response of isolated buildings.
\end{abstract}

keywords : seismic isolation, elastomeric bearing, tension, dynamic loading test, finite element analysis, hysteresis model 免震, 積層ゴム, 引張, 動的載荷試験, 有限要素解析, 復元力モデル

\section{1. はじめに}

現行の免震建物の多くは, 積層ゴムに引張力を作用させないとい う設計クライテリアを採用している。しかし，免震建物の高層化や 形状の多様化といった最近の傾向 ${ }^{1}{ }^{1}$ は, 積層ゴムに引張力が作用す る可能性を増大させ，この設計クライテリアを満足することが困難 な状況を生じさせるようになってきた。，特に，塔状比は免震建物の 計画上大きな制約条件となる。このような現状を背景として引張力 作用下での積層ゴムの挙動に対する関心が高まり, 多くの研究者に より積層ゴムの引張試験が実施され，限界状態に至る応力やひずみ などの条件が明らかにされつつある2 8)。

積層ゴムに引張力が作用する免震建物の地震時挙動については, 建物規模や入力地震動レベルなどの制約により，解析的検討に拠ら ざるを得ないが，既往の研究の多くは積層ゴムの鈶直方向復元力特 性を圧縮と引張をそれぞれ勾配の異なる 2 直線で表現するという簡 易なモデル化に留まり，積層ゴムの実挙動を反映させているとは言 门難い。免震建物の地震時安全性を照査する際に積層ゴムの限界状 態と比較すべき応答值は, 積層ゴムの復元力特性を適切に反映させ たモデルによって得られるべきである。一方，積層ゴムの引張特性 に着目した研究の多くは, 樌層ゴムが破断に至るような限界性能の
把握を主目的としており，限界状態に至る以前の挙動に着目した研 究は少ない。よって，積層ゴムの鈶直方向復元力特性を適切にモデ ル化するために必要な知見はほとんど得られていないと言える。

そこで, 本研究では引張力を受ける積層ゴムの鈶直方向復元力特 性を明らかにすることを目的として掲げた。初めに, 高減衰積層ゴ 么縮小試験体を用いて, 圧縮せん断 -引張せん断の動的載荷試験を 実施した。試験では，積層ゴムのフランジプレートや連結鋼板など のフランジ構造の剛性が積層ざム全体の復元力特性に及ぼす影響を 無視できないと考え, 積層体を同一としフランジ構造の異なる 2 種 類の試験体を用意した。続いて, 動的載荷試験で用いた積層ゴム試 験体を対象に, 有限要素法による圧縮せん断・引張せん断の単調載 荷解析を実施した。解析ではフランジ構造の挙動にも着目して, 櫴 層体とフランジ構造の双方を忠実にモデル化し，動的載荷試験にお ける鈶直初期剛性の再現性ならびに試験では得ることのできない積 層ゴム内部のひずみ分布やフランジ構造の変形状態について検討し た。最後に, 積層ゴムが引張力を受けるような免震建物の地震応答 . 解析への適用を意図して, 動的載荷試験より得られた積層ゴムの鈶 直方向復元力特性の定性的傾向を分析することで, 試験結果を適切 に表現できる復元力モデルを新たに提案した。
本論文の一部は1998年度日本建築学会大会9,10)で発表している。

*1 清水建設和泉研究室 博士(工学)

*2 清水建設設計本部

*3 清水建設技術研究所工修

*4 横浜ゴム MB 開発本部
Izumi Research Institute, Shimizu Corporation, Dr. Eng. Design Division, Shimizu Corporation

Institute of Technology, Shimizu Corporation, M. Eng.

MB New Products Development Division, The Yokohama Rubber Co., Ltd. 


\section{2. 積層ゴムの動的載荷試験 \\ (1) 試験体}

本研究では，積層ゴムの銛直方向復元力特性を把握するために は，積層体のみならず，フランジプレートや連結鋼板などのフラン ジ構造も評価対象とすべきであると考えた。そこで, 図ー 1 に示す ように，積層体を共通としフランジ構造が異なる 2 種類（Type A， B）のフランジ組立型 ${ }^{11)}$ の高減衰積層ゴム試験体を用意した。積層 体は厚さ $2.38 \mathrm{~mm} \times 21$ 層の高减衰ゴムシート $\left(\mathrm{G}=6 \mathrm{kgf} / \mathrm{cm}^{2}\right)$ と, 厚 さ $1 \mathrm{~mm} \times 20$ 層の内部鋼板を加硫接着させた構造であり, 1 次形状係 数は25.2, 2 次形状係数は6である。Type Aは剛なフランジ構造を 想定して，厚さ $25 \mathrm{~mm}$ の連結鋼板のみを有する構造とした。Type B は実機に近いフランジ構造を想定して, 連結鋼板の厚さを $18 \mathrm{~mm}$,

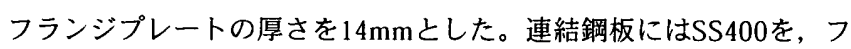
ランジプレートにはSM490を用いた。

\section{(2) 試験方法}

試験では積層ゴムに対して地震応答時に近い荷重状況を与える配 慮から, 図ー 2 に示すような 2 軸試験機を使用して, 初めにオフ

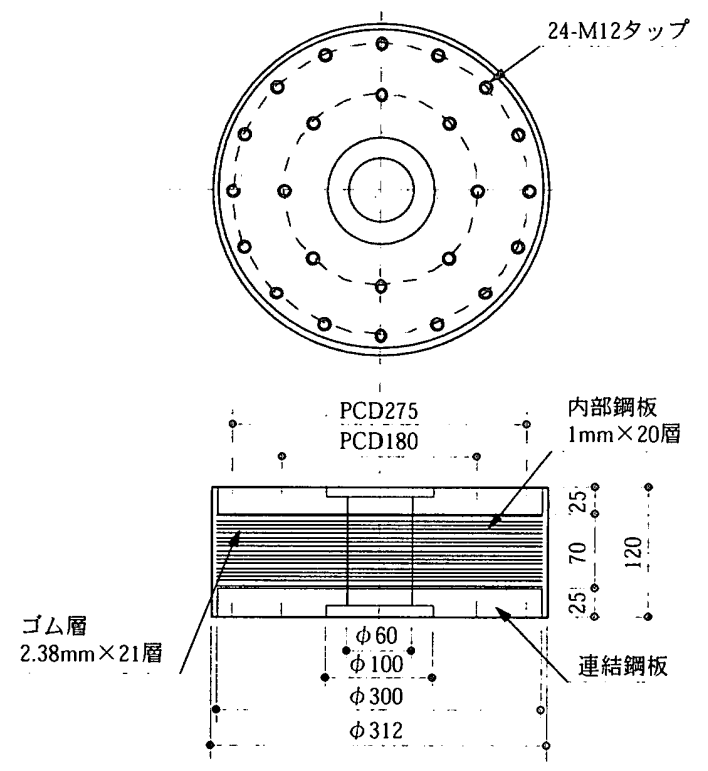

(a) Type A
セットひずみを与え, 続いて圧縮から引張まで軸力を連続的に変化 させる動的繰り返し載荷を行った。積層ゴム試験体は, フランジ構 造の相違を吸収するために, 取付治具プレート $(600 \mathrm{~mm} \times 600 \mathrm{~mm}$, 厚さ $40 \mathrm{~mm}$ の鋼板）を介して試験機へ取り付けた。試験体の鈶直方 向変位は, 加カプレート間に取り付けた非接触型のレーザー変位計 （測定範囲士 $100 \mathrm{~mm}$, 分解能 $50 \mu \mathrm{m}$ ）を用いて計測した。ここで計 測された変形は, 積層体, フランジ構造, 取付治具プレートの変形 を合わせたものである。試験プログラムを表ー 1 に示す。オフセッ トひずみはType Aについては0,100, 200,300\%の 4 水準を, Type B については $0,200 \% の 2$ 水準を設定し，各オフセットひずみ毎に試 験体を用意した。軸力は面圧に換算して $\pm 10 〜 \pm 50 \mathrm{kgf} / \mathrm{cm}^{2}$ まで $10 \mathrm{kgf} / \mathrm{cm}^{2}$ 刻みで変動させ, 載荷繰り返し数は各面圧ごとに10回と した。また, 載荷振動数はType Aの面圧 $\pm 10 \mathrm{kgf} / \mathrm{cm}^{2}$ の載荷につい

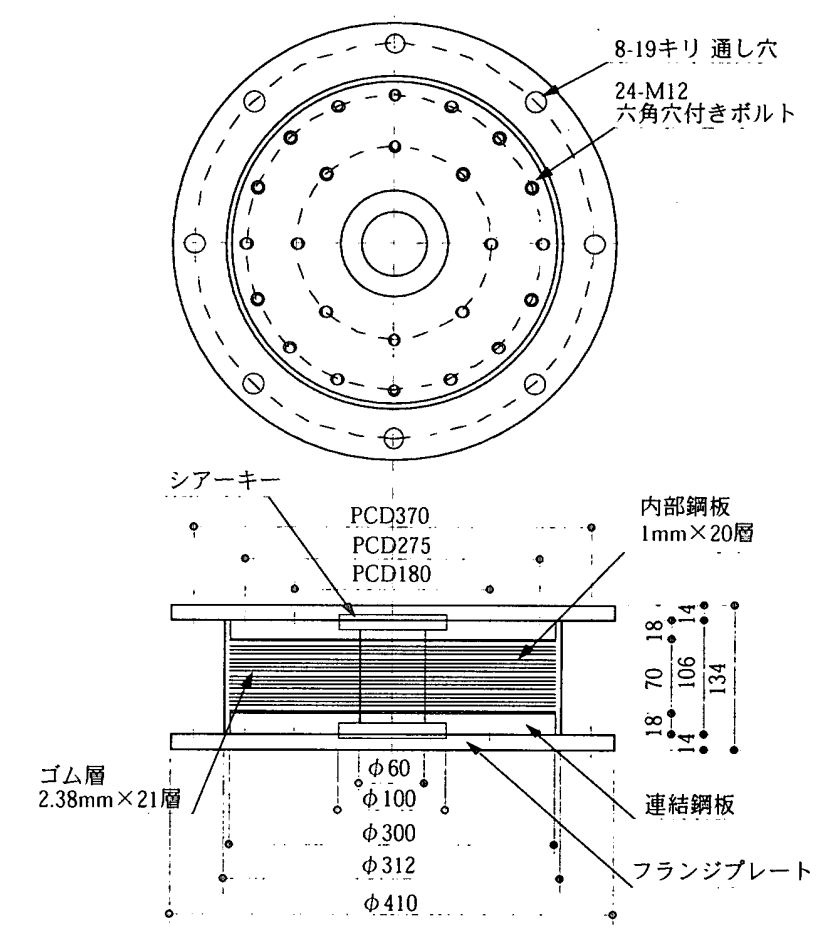

(b) Type B

図-1 積層ゴム試験体の形状

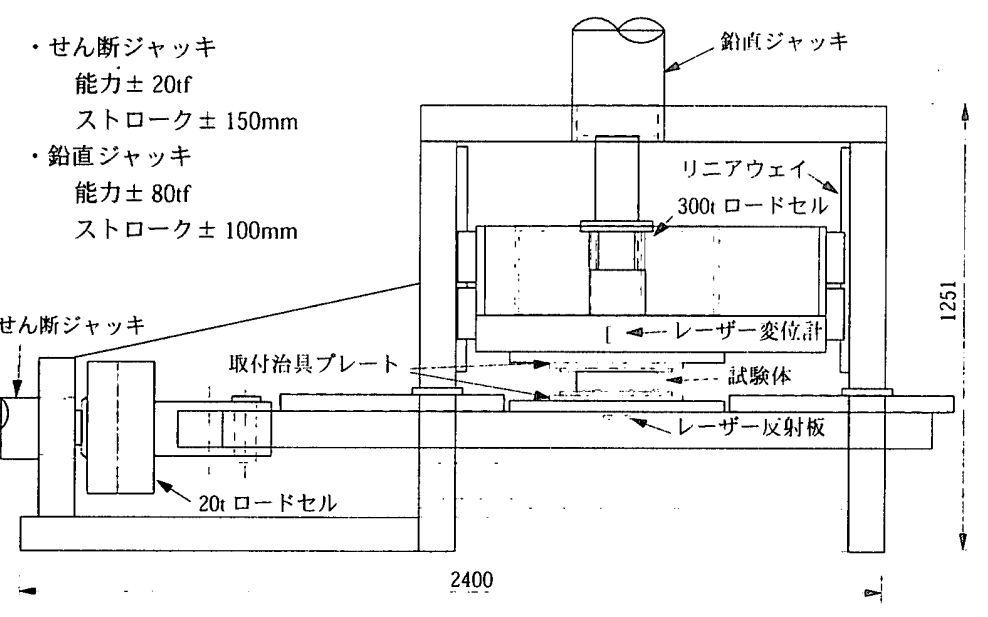

図 -2 試験装置
表 -1 試験プログラム

\begin{tabular}{|c|c|c|c|c|c|}
\hline \multirow{2}{*}{$\begin{array}{c}\text { 面压 }^{1)} \\
\left(\mathrm{kgf} / \mathrm{cm}^{2}\right)\end{array}$} & \multirow{2}{*}{$\begin{array}{c}\text { オフコセット } \\
\text { ひずみ } \\
(\%)\end{array}$} & \multirow{2}{*}{$\begin{array}{c}\text { 振動数 }{ }^{2)} \\
(\mathrm{Hz})\end{array}$} & \multirow{2}{*}{$\begin{array}{l}\text { 繰り返し } \\
\text { 数 (回) }\end{array}$} & \multicolumn{2}{|c|}{ 試験体 3 ) } \\
\hline & & & & Type A & Typc B \\
\hline \multirow{4}{*}{$\begin{array}{c} \pm 10 \\
\pm 20 \\
\pm 30 \\
\pm 40 \\
( \pm 50)\end{array}$} & 0 & \multirow{4}{*}{$\begin{array}{c}0.5 \\
(1.0) \\
(5.0)\end{array}$} & \multirow{4}{*}{10} & 0 & 0 \\
\hline & 100 & & & 0 & - \\
\hline & 200 & & & 0 & 0 \\
\hline & 300 & & & 0 & - \\
\hline
\end{tabular}

1) ( )内の面圧については, それ以下の面圧において耐力低下も しくは試験機の限界ストロークに達したために未実施の載荷っ ースあり。

2）（）内の振動数は, TypeAにおいて面圧 $\pm 10 \mathrm{~kg} / \mathrm{cm}^{2}$ のみ実施。

3）．：試験を実施。一：試験を実施せず。 

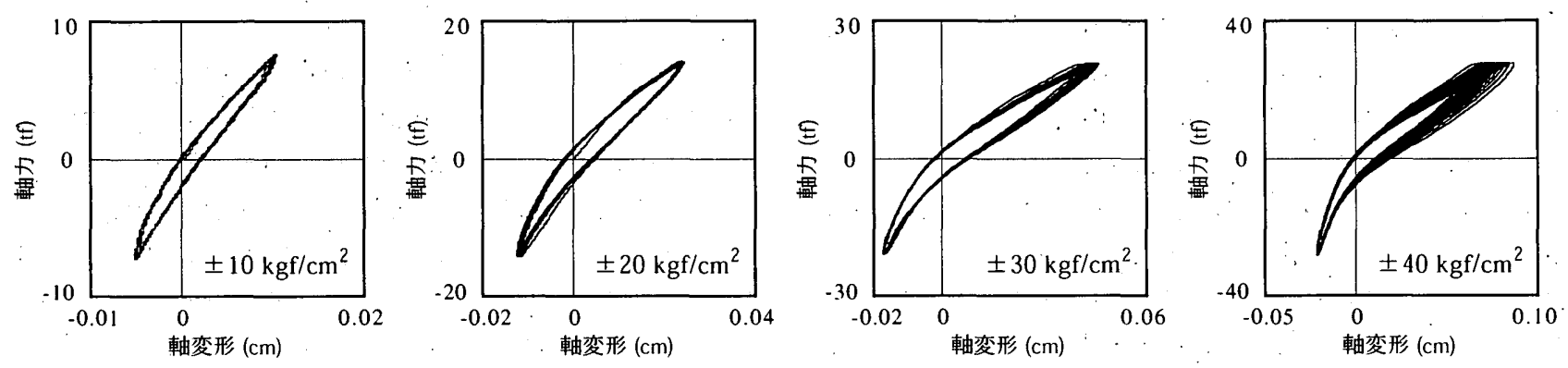

図－3 試験体TypeA，オフセットひずみ $0 \%$ における荷重変形関係
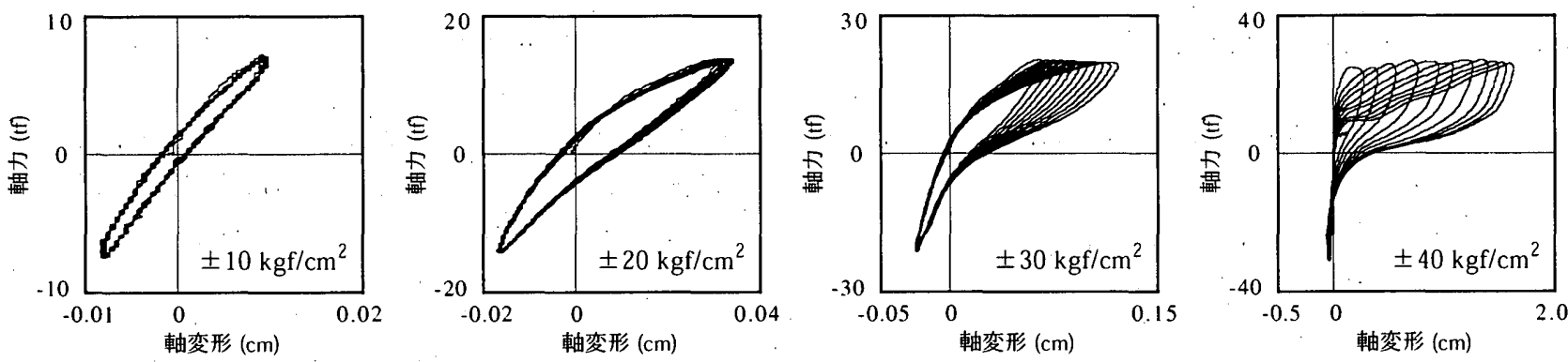

図ー4，試験体TypeA，オフセットひずみ200\%における荷重変形関係
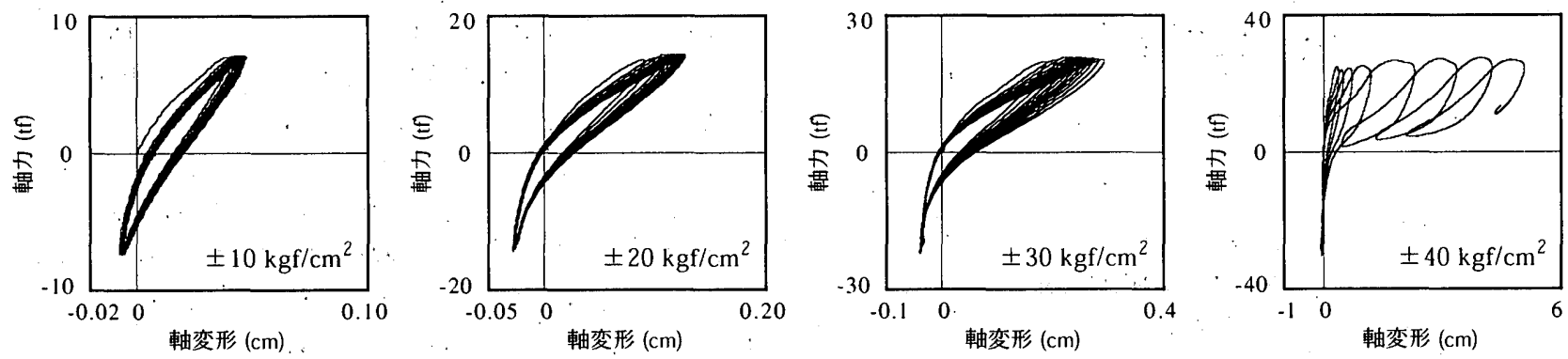

図一 5 試験体TypeB，オフセットひずみ0\%における荷重変形関係
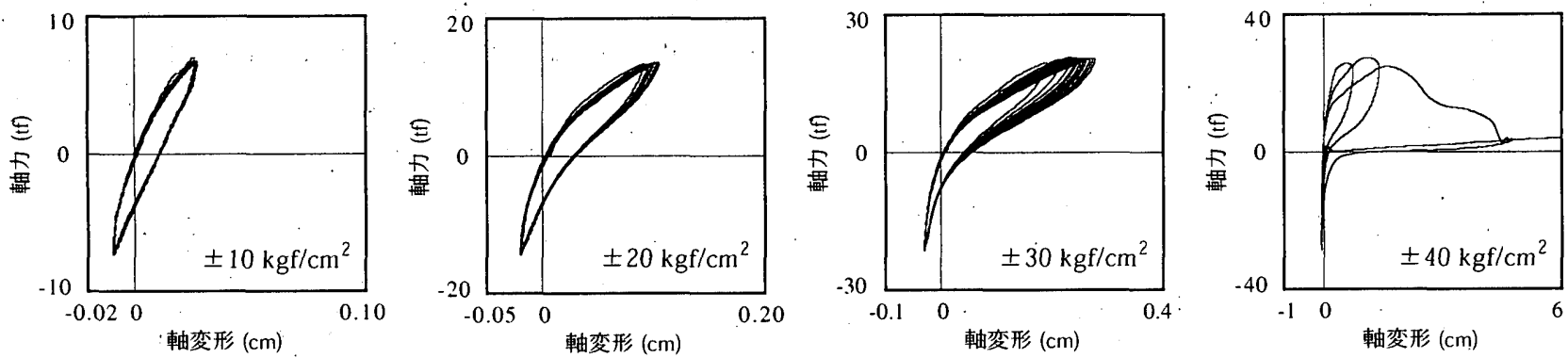

図-6 試験体TypeB，オフセットひずみ200\%における荷重変形関倸

てのみ $0.5,1.0,5.0 \mathrm{~Hz} の 3$ 水準の振動数を設定し，それ以外はすべて $0.5 \mathrm{~Hz}$ とた。なお，本論文では軸力および面圧の符号は，引張を プラス，圧縮をマイナスとする。

\section{(3) 試験結果}

Type Aのオフセットひずみ $0 \%$ 荷重変形関係を図ー 3 に，オフ セットひずみ $200 \%$ の荷重変形関係を図ー4に示す。面圧士10kgf/ $\mathrm{cm}^{2}$ ではオフセットひずみによる履歴ループ形状の変化は少なく, 圧縮領域と引張領域でほぼ対称の履歴ループとなった。面圧振幅が 増大すると圧縮領域での変化はあまり見られないが，引張領域では 剛性低下が生じ非対称性が強くなる。面圧 $\pm 20 \mathrm{kgf} / \mathrm{cm}^{2}$ 以上の面圧 振幅では，オフセットひずみ $200 \% の$ 方が $0 \%$ より引張領域での剛性 低下が顕著となり，面圧土 $40 \mathrm{kgf} / \mathrm{cm}^{2}$ では荷重增分がほぼ頭打ちと
なり変形が急激に増大した。なお，図示はしていないが，オフセッ トひずみ $0 \%$ て面圧士 $50 \mathrm{kgf} / \mathrm{cm}^{2}$ の載荷において，オフセットひず み $200 \%$ の面圧 $\pm 40 \mathrm{kgf} / \mathrm{cm}^{2}$ と同様の履歴ループ性状を示して, 急激 に変形が增大した。

Type Bのオフセットひずみ0\%の荷重变形関係を図ー 5 に，オフ セットひずみ $200 \%$ の荷重変形関係を図－6に示す。面圧振幅の增 大とともに引張領域での剛性低下が顕著となり，履歷ループの非対 称性が強くなる傾向はType Aと同様である。しかし, 面圧士30kgf/ $\mathrm{cm}^{2}$ までは，オフセットひずみの違いによる履歴ループ形状の変化 は少ない。また，面圧 $\pm 40 \mathrm{kgf} / \mathrm{cm}^{2}$ ではオフセットひずみに関係な く荷重增分が頭打ちとなり, 変形が急激に増大した。

Type AとType Bの履歴ループを; 同一オフセットひずみ, 同一面 
圧振幅の条件下で比較すると, Type Bの方が引張領域における剛性 低下が大きい。両タイプの違いは，連結鋼板およびフランジプレー トの厚さにあり，積層ゴム全体の鉛直方向復元力特性に対してフラ ンジ構造の寄与が大きいことを示している。

Type A, Bともに, 荷重増分の頭打ち以後に見られた変形の急激 な增大は, コムムの破断に始まり, 続いてゴム破断部付近の内部鋼板 が面外へ大きく変形することによって生じたものである。Type Aの オフセットひずみ0\%では試験機のストロークにより完全に破断には 至らなかったが，それ以外の試験では最終的にゴム部が全断面に 渡って破断に至った。フランジプレート，連結鋼板，取付治具プ レートおよびボルトには残留変形は認められなかった。

図ー 7 にType Aの面圧振幅 $\pm 10 \mathrm{kgf} / \mathrm{cm}^{2}$ の載荷試験より得られた 初期剛性と載荷振動数との関係を示す。圧縮初期剛性は, 最大圧縮

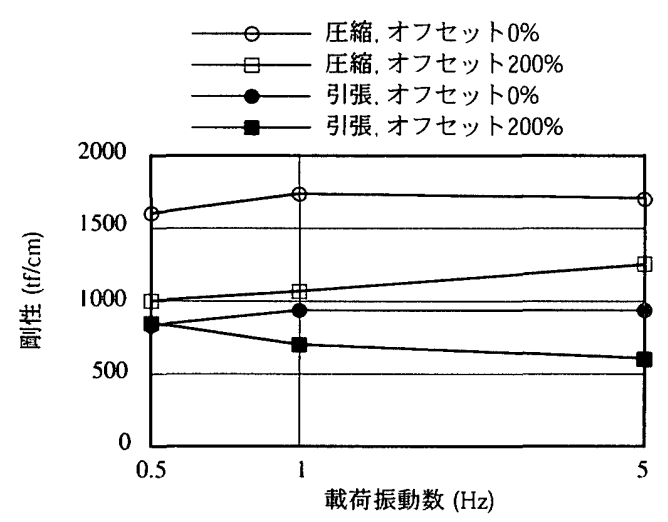

図 - 7 載荷振動数 と初期剛性の関係 (Type A, 面圧振幅 $\pm 10 \mathrm{kgf} / \mathrm{cm}^{2}$ )
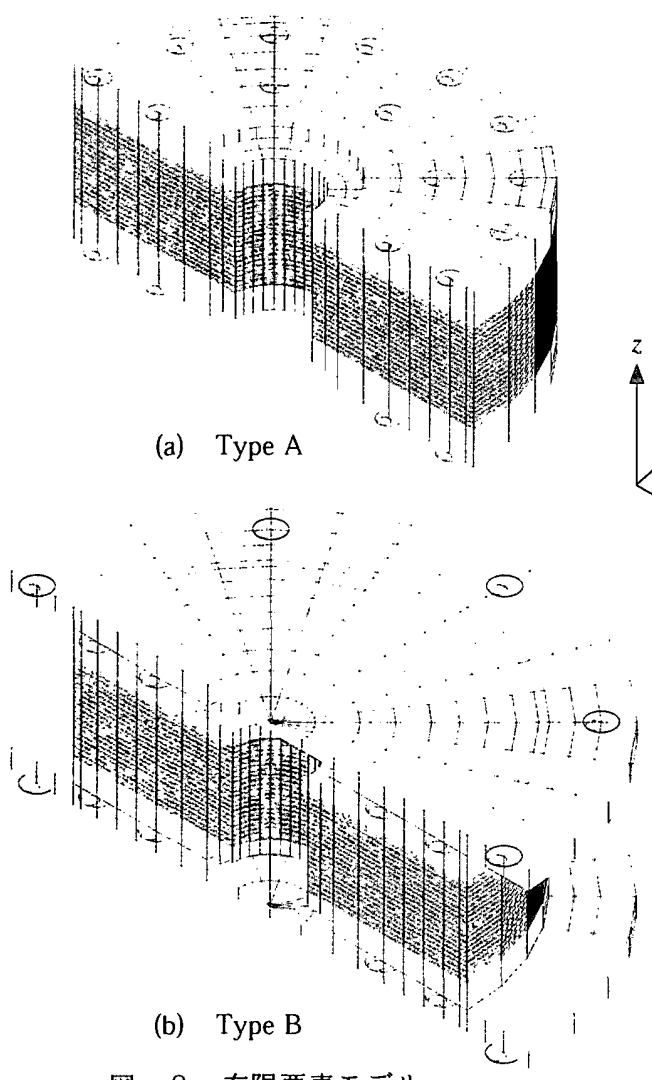

図一8 有限要素モデル
荷重点と圧縮除荷曲線における最大圧縮荷重の $50 \%$ の点を結ぶ直線 の勾配と定義した。また, 引張初期剛性は, 圧絔から引張へ移行す る際の荷重ゼ口点と引張載荷曲線における最大引張荷重の $10 \%$ 点 を結ぶ直線の勾配と定義した。10回の繰り返し載荷の中で3ループ 目の荷重変形曲線に対して, 上述の定義を適用して初期剛性を算出 した。圧縮剛性, 引張剛性ともに載荷振動数により $20 \%$ 程度の剛性 変化が見られる。しかし, 剛性変化に一定の傾向はなく, 本試験で 行った振動数 $0.5 \sim 5 \mathrm{~Hz}$ の範囲の載荷では, 鈶直剛性に対する載荷振 動数の影響は見られなかった。

\section{3. 皘層コムムの有限要素解析}

(1) 解析モテル

動的載荷試験で用いた積層ゴム試験体の $1 / 2$ を図ー 8 のように 3 次 元有限要素でモデル化して, 圧䈹せん断および引張せん断の単調載 荷解析を行った。解析コードはABAQUS (Ver5.7) ${ }^{12)}$ を使用した。

積層体のゴム部は 8 節点ソリッド要素（超弾性ハイブリッド要 素）を用い, 積層体の内部鋼板, および連結鋼板とフランジプレー 卜は 6 節点あるいは 8 節点のソリッド要素（弾性アイソパラメト リック要素) を用いてモデル化した。積層体のゴム部と内部鋼板, および連結鋼板とフランジプレートは，すべて円周方向に32分割と した（ただし，1/2モデルにより16分割）。また, 積層体の内部鋼板 は一層あたり厚さ方向に 1 分割, ゴム部は変形が大きいことから一 層あたり 3 分割とした。

さらに，引張状態での復元力特性には積層体のみならずフランジ 構造の剛性が影響すると考え, 図ー 9 に示すように連結鋼板, フラ ンジプレート, ボルト, シアーキー, 各部材の接触面についても詳 細なモデル化を施した。ボルトは， $z$ 方向のみに自由度を有するスプ リング要素と $x-y$ 平面内の相対変形を拘束するギャップ要素に置換し た。連結鋼板とフランジプレートの間にあるシアーキーは，接触面 の $x$ - $y$ 平面内の相対変形をギャップ要素により拘束した。同様に, ボ ルト位置を除くType Aの連結鋼板上下面, あるいはType Bのフラン
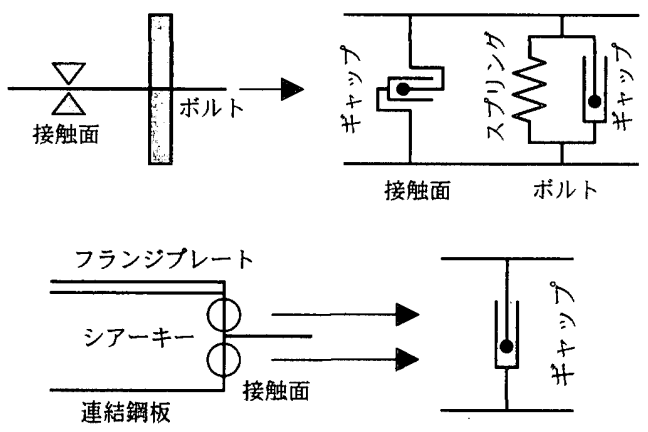

図-9 フランジ構造のモデル化

表 -2 有限要素モデルの諸元

\begin{tabular}{|c|c|c|c|}
\hline \multicolumn{2}{|r|}{ タイプ } & Type A & Type B \\
\hline \multirow{3}{*}{$\begin{array}{l}\text { 要 } \\
\text { 素 } \\
\text { 数 }\end{array}$} & ソリッド要素 & 12464 & 13168 \\
\hline & スプリング要素 & 144 & 362 \\
\hline & ギャップ要素 & 28 & 38 \\
\hline & 節点数 & 24845 & 26606 \\
\hline
\end{tabular}


ジプレート上下面と躯体との接触面，およびType Bの連結鋼板とフ ランジプレートの接触面についても, $z$ 方向の相対変形をギャップ要 素により拘束した。積層ゴム下面のフランジプレートに取り付くボ ルトの下端（躯体側）の節点は固定し, 積層ゴム上面のフランジプ レートに取り付くボルトの上端（躯体側）の節点に $x$ 方向の強制変 位を与えることでオフセットひずみを導入し， $z$ 方向に荷重を作用さ せることで鈶直荷重を導入した。'各節点に与える強制変位はすべて 同一とし，各節点に作用させる鈶直荷重はそれらの合計值が（所定 の面圧×積層コムムの断面積）となるように制御した。以上のような 積層ゴム各部のモデル化および要素分割により，有限要素モデルの 諸元は表一2のようになった。

ゴム材料の構成則には, Mooney-Rivlinのひずみエネルギ一密度 関数 ${ }^{13)}$ を用いた。高減衰ゴムはせん断ひずみに依存してせん断弾性 率が変化する性質を有するが，このような高隇衰ゴム特有の挙動を 適切に評価する構成則は現在得られていない。そこで, 本解析では $\mathrm{G}=6 \mathrm{kgf} / \mathrm{cm}^{2}$ 相当の天然ゴム板（厚さ $1.6 \mathrm{~mm}, 100 \mathrm{~mm} \times 100 \mathrm{~mm}$ )の 一軸拘束・二軸引張試験結果を適用し，体積弾性率を $20,000 \mathrm{kgf} / \mathrm{cm}^{2}$ と仮定することによって, 高減衰ゴム材料のモデル化を行った。以 上のような材料定数の設定により，ゴムのポアソン比は0:49995と なった。・

\section{(2) 解析方法}

一般的に, ゴムが引張力を受け内部にボイドが発生する状況下で は, 本解析で用いたひずみエネルギ一密度関数の適用は困難であ り, 引張載荷解析ではゴム内部にボイドが発生する以前の載荷状態 に留める必要がある。したがって; 動的載荷試験のシミュレーショ ン解析を゙行うにあたり,ここではゴムに過大な引張力が作用しない 範囲内で試験結果との比較を行うこととし, 圧縮および引張の初期 剛性に着目した検討を行う。

初めにオフセット変形を $x$ 方向に与え，所定のオフセットひずみ に達した時点で圧縮あるいは引張方向に鈶直荷重を作用させた。圧 縮載荷解析にういては, 面圧-20kgf $/ \mathrm{cm}^{2}$ 相当の荷重を $z$ 方向に加え た。各オフセット変形状態における圧縮剛性は, 面圧 $-20 \mathrm{kgf} / \mathrm{cm}^{2}$ に達した時点での積層ゴム全体の鈶直変位量と鈶直荷重から評価し た。引張載荷解析では, 面圧 $2 \mathrm{kgf} / \mathrm{cm}^{2}$ 相当の荷重をz方向に加え, 引 張平均面圧が $1 \mathrm{kgf} / \mathrm{cm}^{2}$ から $2 \mathrm{kgf} / \mathrm{cm}^{2}$ に変化する際の積層ゴム全体の 鈶直変位量と鈶直荷重から引張剛性を評価した。さらに, 引張載荷 解析では載荷試験において積層ゴム試験体の上下面と試験機との間

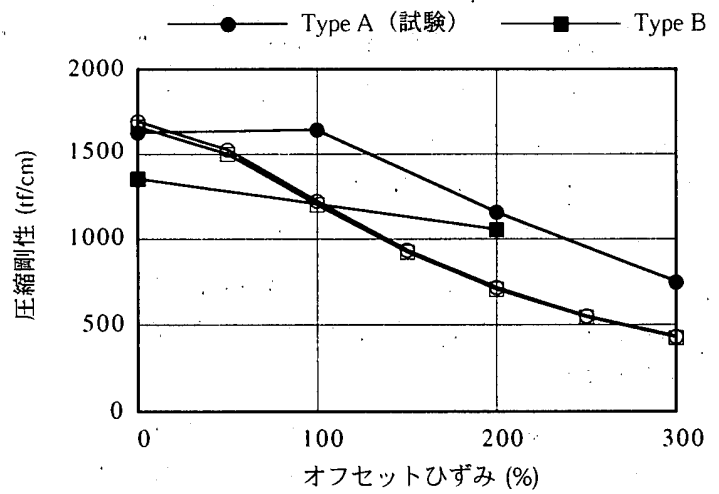

(a) 圧縮剛性
に介在する取付治具プレートの剛性を考慮した。治具プレートのみ を有限要素によりモデル化し，積層ゴムの解析で得られたボルト位 置での反力を治具プレートに加えることにより，治具プレートの引 張剛性を評価した。試験結果と比較すべき引張剛性 $K_{T}$ は, 櫴層ゴム のばねの上下に治具プレートのばねが取りついた 3 本のばねの直列 の系により評価するものとし, 積層ゴムの引張剛性 $K_{1}$ と治具プレー トの引張剛性 $K_{2}$ から(1)式により算出した。

$$
\frac{1}{K_{T}}=\frac{1}{K_{1}}+\frac{2}{K_{2}}
$$

\section{（3）解析結果}

解析によって得られた圧縮および引張の初期剛性とオフセットひ ずみとの関係を、試験結果と比較して図ー10に示す。なお，試験結 果については圧縮, 引張ともに面圧土 $20 \mathrm{kgf} / \mathrm{cm}^{2}$ 載荷時の荷重変形 関係から得られた初期剛性を採用した。

圧縮剛性については, 試験, 解析ともにオフセットひずみが増大 するに従い低下する傾向が見られる。試験結果ではType AとType B で差が見られるが，解析結果ではいずれのタイプもほぼ同じ剛性と なっている。また，オフセットひずみ $0 \%$ オは解析結果と試験結果に 良い対応が見られるが，それ以外のオフセットひずみでは解析結果 は試験結果の60～70\%程度の値となっている。

引張剛性については, 試験, 解析ともにType Aではオフセットひ ずみが增大するに従い引張剛性は低下するが, Type Bではオフセッ トひずみによらずほぼ一定の引張剛性となる傾向が見られる。Type

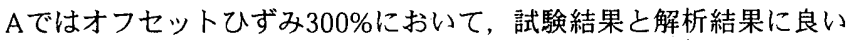
対応が見られるが，それ以外のオフセットひずみでは圧縮剛性と同 様に, 解析結果は試験結果の70\%程度の值となっている。Type Bに ついては，0〜300\%のオフセットひずみ全般に渡って比較的良い対 応が見られる。

オフセットひずみ $0 \%$ 場合の連結鋼板とフランジプレートの変形状態を, 変形倍率を同一 として図ー11に示す。Type Aの連結鋼板にはほとんど変形は見られ ないが, Type Bの連結鋼板とフランジプレートは大きく湾曲してい る。また, Type Bでは外周部および内周部において連結鋼板とフラ ンジプレートとの間に隙間も見られる。さらに, 図ー 11 と同一の荷 重条件における積層体端部のゴム部の主ひずみの分布（主ひずみ $\varepsilon_{1}$, $\varepsilon_{2}, \varepsilon_{3}\left(\varepsilon_{1}<\varepsilon_{2}<\varepsilon_{3}\right)$ における $\left.\varepsilon_{3}\right)$ を図一12に示す。 Type Aではひずみの 大きな領域が外周部と中心部に存在し, ひずみ分布が比較的均一で

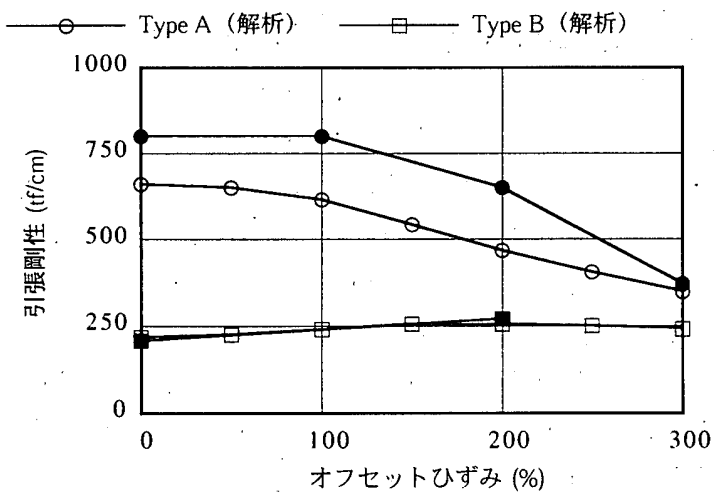

(b) - 引張剛性

図一10 オフセットひずみと初期剛性の関係 


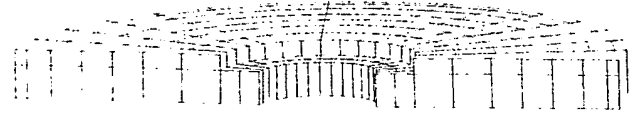

(a) Type $\mathrm{A}$

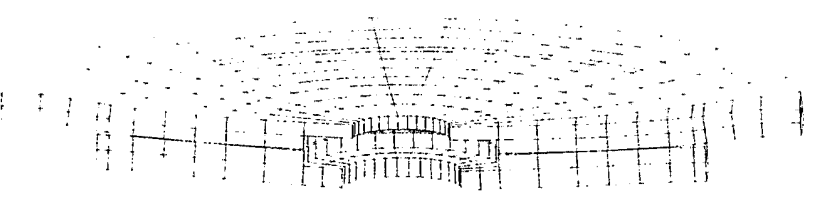

(b) Type B

図-11 引張力を受ける樻層ゴムの連結鋼板 およびフランジプレートの変形状態

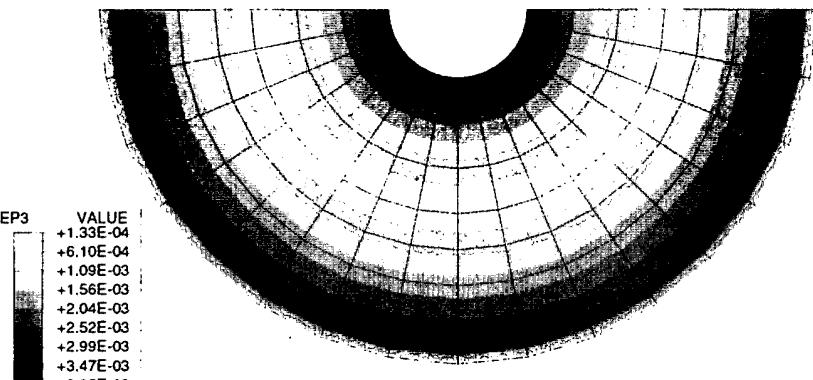

(a) Type A

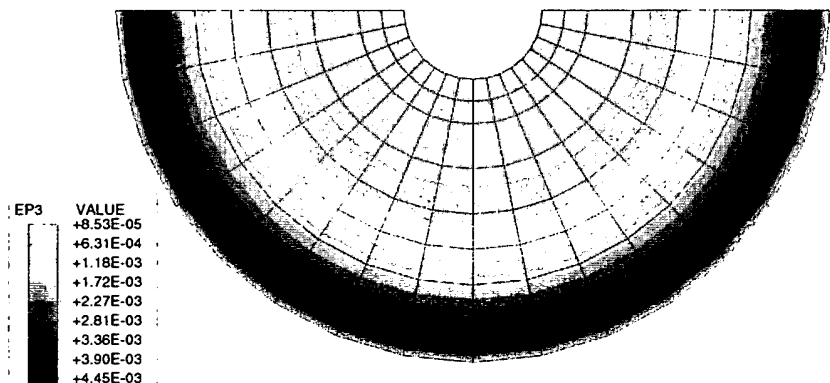

(b) Type B

図ー12 引張力を受ける積層ゴム端部のゴム部主ひずみ分布 (主ひずみ $\varepsilon_{1}, \varepsilon_{2}, \varepsilon_{3}\left(\varepsilon_{1}<\varepsilon_{2}<\varepsilon_{3}\right)$ における $\left.\varepsilon_{3}\right)$

あるのに対して, Type Bではひずみの大きな領域が外周部に偏って いる。また, Type Bの方が主ひずみの最大值 $\left(\varepsilon_{3, \max }\right)$, および主ひず みの最小值 $\left(\varepsilon_{3, \mathrm{~min}}\right)$ がType Aより大きく, 半径方向に対するひずみの 変化も著しい。なお, Type A, Bともに半径方向の中間部分にひず みの小さな領域が存在するが，これは自由表面から内部に入るに 従って内部鋼板によるゴムの変形拘束効果が高まるためであると考 えられる。積層ゴムの限界状態に関する議論は本論文の対象範囲外 ではあるが, フランジ構造の剛性がゴムのひずみに影響を与えるこ とは，ゴムの破断と関連づけられる積層ゴムの限界状態に対する留 意点の一つとしてとらえるべきであろう。

以上のように, フランシジ構造の剛性は積層ゴムの引張剛性や積層 体のゴム部のひずみに大きな影響を与えることがわかる。オフセッ トひずみに依存して積層ゴムの圧縮剛性が変化することは, 積層体 のせん断変形に伴う鈶直荷重の有効支持領域の変化と関連づけられ ることが, 既往の研究 ${ }^{14.15}$ において報告されている。一方, フラン
ジ構造は積層体のように大きくせん断変形することはなく，その剛 性にはオフセットひずみ依存性はない。積層ゴム全体の鈶直剛性 は，積層体の剛性とフランジ構造の剛性が直列に接続する系として 評価されている5)。すなわち，(1)式において取付治具プレートの剛 性 $K_{2}$ をフランジ構造の剛性に, 積層ゴムの剛性 $K_{1}$ を積層体の剛性に 置き換えて評価できる。したがって，フランジ構造が剛であれば, 積層ゴム全体の引張剛性に対する積層体の剛性の寄与が相対的に大 きくなり，引張剛性に対してもオフセットひずみ依存性が影著にな る。しかし, フランジ構造の剛性が小さい場合には, 逆に積層ゴム 全体の引張剛性に対するフランジ構造の剛性の寄与が大きくなり, 積層体のオフセットひずみ依存性は相対的に小さくなると考えられ る。フランジ構造の剛性が大きいType Aでは引張剛性に対してもオ フセットひずみ依存性が顕著であったが，フランジ構造の剛性が小 さいType Bではオフセットひずみ依存性が顕著に見られなかったこ とは，上述の理由によるものと考えられる。また，Type A, Bの圧 縮剛性ならびにType Aの引張剛性に関して, 解析結果は試験結果の 60〜70\%程度であり, 高減衰ゴム材料のモデル化については改良の 余地が残されていると言える。一方, Type Bの引張剛性に関して, 試験結果と解析結果が良く対応している理由の一つとして，フラン ジ構造の寄与が大きくなった分, 積層体の影響が相対的に小さく なったことが考えられる。

\section{4. 積層ゴムの鉛直方向復元カモテル \\ （1）積層ゴム動的載荷試験結果の分析}

積層ゴムの鉆直方向復元力モデルの構築に先立ち, 図-3〜6に 示した試験結果を分析することで，復元力特性に関して以下のよう な定性的傾向を把握した。

(1) 圧縮領域はほほ線形と見なせる。

(2) 引張載荷時には載荷直後からソフトニングが生じる。

(3) 繰り返し引張載荷による剛性低下が見られる。

(4)引張除荷時には面圧の增大に伴いスリップ性状を示す。

(5) 引張載荷に対しては残留変形が生じ，その変形量は剛性低下とと もに徐々に大きくなる。

免震建物の地震応答解析において，積層ゴムの鈶直方向復元力モ デルとして多用されている圧縮と引張を勾配の異なる 2 本の直線で 表現する簡易な復元力モデルでは，上述のような定性的傾向を表現 することができない。また, 引張領域の荷重変形関係を曲線によっ て表現した既往の復元力モデルにおいても, 繰り返し載荷による剛 性低下や残留変形の增大が考慮されてはいない。地震時に一部の積 層ゴムに引張力が作用し他の構面へ基礎梁を介して引張力が伝達さ れる状況下では，わずかな復元力特性の違いによって基礎梁に作用 するせん断力に大きな差が生じる ${ }^{16)}$ 。したがって，積層ゴムに引張 力が生じるような免震建物の地震時挙動を把握するには，上述の定 性的傾向に見られるような引張領域における非線形挙動を適切に表 現できる復元力モデルを用いることが必要である。

\section{(2) 復元カモデルの提案}

前項で記述した状況を踏まえ，本研究では可能な限り実挙動に近 い復元力特性を表現できるモデルを新たに構築する。提案する復元 力モデルには, 載荷直後から非線形となる引張領域の荷重変形関係 に対して曲線を適用した。ただし，扱いやすい関数形であること 


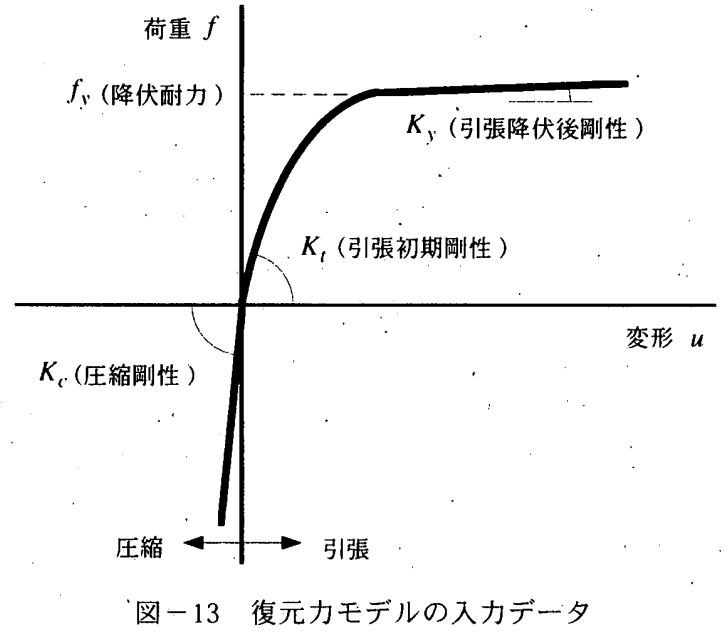

（微分, 積分が容易）, 履歴則が単純であること, 記憶すべき情報 量を極力少なくすることを配虑した。また, 引張領域での対象を ハードニシグ以前までとし，オフセットひずみの影響は無視した。 このような復元力モデルの構築方針から, 履歴則は圧縮載荷・圧縮 除荷, 引張載荷, 引張除荷の 3 ケースのみの単純な構成とし, 入力 データは以下の 4 つ゚の物性值とした（図ー13参照）。

$K_{c}$ ：圧縮剛性

$K_{t}:$ 引張初期剛性

$K_{y}:$ : 引張降伏後剛性

$f_{y}:$ : 引張降伏荷重

前項で述べた試験結果の定性的傾向の分析から, 圧縮載荷・圧縮 除荷には 1 次関数, 引張載荷には $e$ 関数, 引張除荷には 3 次関数が 適当であると判断し，各ケースにおける荷重変形関係を(2)〜 (4) 式 のように表現した（図ー14参照）。また，非線形となる引張領域に はMasing則を適用せず，最大経験変位と直前の荷重反転時の情報の みを用いて荷重変形関係を決定することで，記憶すべき情報量を少 なくした。

(1) 圧縮載荷・圧縮除荷

$$
f=K_{c} \cdot x
$$

(2) 引張載荷

$$
f=K_{y}\left(u-u_{s}\right)+f_{y}\left\{1-e^{-\gamma \frac{K_{t}-K_{y}}{f_{y}}\left(u-u_{s}\right)}\right\}
$$

(3) 引張除荷

$$
f=\frac{f_{r}+f_{t}}{2}+A\left(u-\frac{u_{r}+u_{t}}{2}\right)^{3}+B\left(u-\frac{u_{r}+u_{t}}{2}\right)
$$

ただし，

$$
A=\frac{K_{r} u_{i}-f_{i}}{2 u_{i}^{3}}, B=\frac{3 f_{i}-K_{r} u_{i}}{2 u_{i}}, u_{i}=\frac{u_{r}-u_{t}}{2}, f_{i}=\frac{f_{r}-f_{t}}{2}
$$

(3)式の $u_{s}$ は引張除荷からの再載荷（(3) 一(2)）において，(3)式が反 転位置を通るようにするための変位シフト量である。また， $\gamma$ は繰 り返し載荷による剛性低下率である。 $\gamma$ は(5)式によって算定するも のとし, 最大経験変位 $u_{\max }$ に応じて $1 \dot{\sim} 0$ の值を連続的にとる。

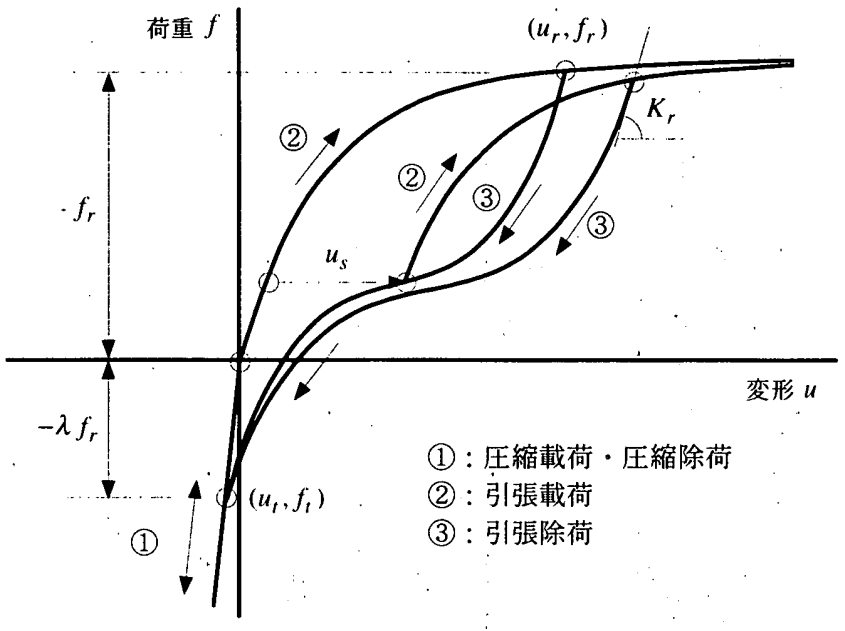

図-14 復元力モデルの履歴則

$$
\left.\begin{array}{ll}
\gamma=1 & \left(u_{\max } \leq u_{y}\right) \\
\gamma=1-\alpha\left(1-\frac{u_{y}}{u_{\max }}\right) & \left(u_{\max }>u_{y}\right)
\end{array}\right\}
$$

ここで, $u_{y}$ は引張降伏変位 $\left(=f_{\mathrm{l}} / K_{t}\right), \alpha$ は剛性低下指数であり, $\alpha$ を 増大させると繰り返しによる剛性低下が著しくなるような効果をも たらす。

(4)式における $\left(u_{r}, f_{r}\right)$ は, 引張載荷(2)からの除荷点である。また, $\left(u_{t}, f_{t}\right)$ は (4) 式の指向点であり, 除荷時の荷重 $f_{r}$ に応じて $(6)$ 式によ り決定される。

$$
f_{t}=-\lambda f_{r}, \quad u_{t}=\frac{f_{t}}{K_{c}}
$$

$K_{r}$ は引張載荷(2)からの除荷剛性であり，(7)式により決定される。 (6)式中の入は，引張除荷(3)の曲線が圧縮載荷・圧縮除荷(1)の直線上 の点を指向する際に, 指向点の荷重が引張除荷時の荷重 $f_{r}$ に関連す ると仮定して導入されたパラメータである。

$$
K_{r}=\min \left(\frac{\mu\left(f_{r}-f_{t}\right)}{u_{r}-u_{t}}, K_{t}\right)
$$

$\mu$ は， $K_{r}$ が引張除荷点と引張除荷(3)の曲線の指向点を結んだ直線 の勾配に関連すると仮定して導入したパラメータである。ただし， $K$ ，以下とする制限を設けることで, 引張除荷(3)曲線が引張除荷中 に負勾配となる不自然な状況を防ぐ。

(5) （7)式におけるパラメー夕 $\alpha, \lambda, \mu$ は積層ゴムの物性から求め られる性質のものではなく, (2)〜 (4)式で表現された復元力モデル において，履歴ループの形状を操作するために便宜上導入されたも のである。したがって, 各パラメータの変化が荷重変形関係に及ぼ す影響を踏まえて，経験的に設定する必要がある。また; (5)式や (7)式のような $\gamma, K_{r}$ の算定式についても同様である。

\section{（3）動的載荷試験のシミュレーション解析}

提案した復元力モデルの妥当性を検証するために, 動的載荷試験 のシミュレーション解析を行った。ここではType A，Bのオフセッ トひずみ $0 \%$ 試験結果を解析対象とした。入力データのうち剛性お よび降伏荷重については, “試験より得られた值を反映させた。Type Aでは圧縮剛性を $1626 \mathrm{tf} / \mathrm{cm}$, 引張初期剛性を $800 \mathrm{tf} / \mathrm{cm}$, 降伏荷重を 

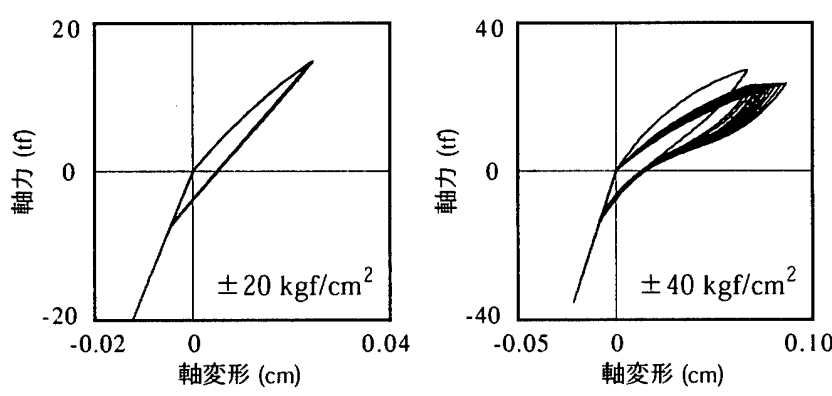

図－15 試験体TypeA，オフセットひずみ0\%の解析結果
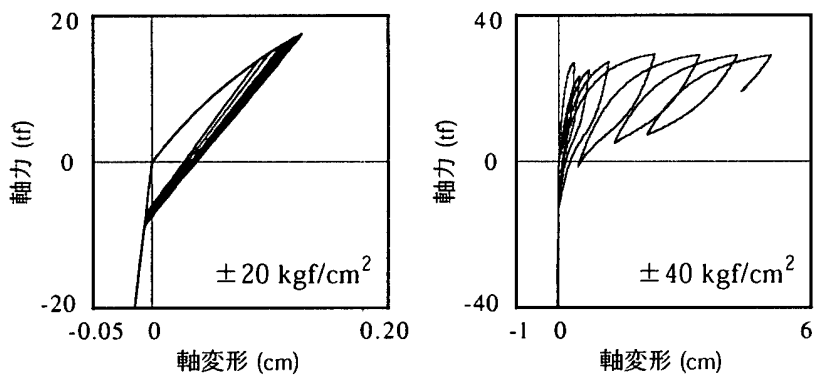

図ー16 試験体TypeB，オフセットひずみ0\%の解析結果

$30 \mathrm{tf}$ とし, Type Bでは圧縮剛性を $1356 \mathrm{tf} / \mathrm{cm}$, 引張初期剛性を $200 \mathrm{tf} /$ $\mathrm{cm}$, 降伏荷重を $35 \mathrm{tf}$ とした。さらに, 引張降伏後剛性はType A, B

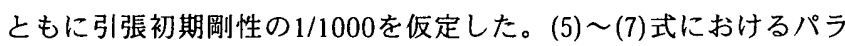

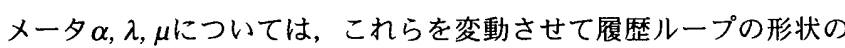
変化を検討した結果， $\alpha=0.9, \lambda=0.5, \mu=2.0$ とした場合に比較的試験 結果に近い履歴ループの形状を得ることができた。試験で得られた 変位波形を復元力モデルに入力することで, 各変位履歴に対応する 荷重を算出して描いた荷重変形関係を図ー15,16に示す。図一 3 と 図ー15, および図ー 5 と図-16を比較すると, 動的載荷試験による 荷重変形関係で見られた引張載荷直後のソフトニング, 繰り返し引 張載荷による剛性低下と残留変形の増大, 引張領域における荷重頭 打ちと急激な变形の増大などの特徵が良好に再現されていることが わかる。

\section{5. まとめ}

本研究では, 引張力を受ける積層ゴムの鉛直方向復元力特性を明 らかにすることを目的として，積層ゴムの圧縮せん断・引張せん断 の動的載荷試験と有限要素解析を実施した。一連の動的載荷試験な らびに有限要素解析の結果から得られた知見を要約すると以下のよ うになる。

(1) 積層ゴムの連結鋼板やフランジプレートなどのフランジ構造の剛 性は，積層ゴム全体の引張剛性に大きな影響を及ぼす。

(2) 圧縮剛性で見られたオフセットひずみ依存性は, 引張剛性では連 結鋼板やフランジプレートが薄くなるとともに小さくなる。

(3) 本研究で実施した $0.5 \sim 5 \mathrm{~Hz}$ の載荷振動数の範囲では, 積層ゴム の鈶直剛性に対する載荷振動数の影響は見られない。 本研究で用いた積層ゴム縮小試験体よりも, 実建物で用いられる 積層ゴムの方がフランジ構造の剛性が積層体の剛性より相対的に小 さくなることから，(1)と(2)の傾向は一層顕著になる。したがって， 積層ゴムに引張力が作用する免震建物の挙動を考える場合, 積層体 のみならずフランジ構造の剛性を評価することが重要となる。
さらに, 本研究では積層ゴムの鉛直方向復元力特性を適切に表現 するための復元力モデルを新たに提案した。本復元力モデルを用い ることによって, 動的載荷試験で得られた荷重変形関係を良好に再 現することができた。本復元力モデルは，免震建物の地震応答解析 モデルの作成において，積層ゴムの鈶直剛性を置換する際の非線形 ばねに適用することを意図している。このモデルを用いて地震応答 解析を行うことにより, 積層ゴムに引張力が作用する免震建物の地 震時挙動がより高い信頼性をもって評価できると考えられる。

本研究で載荷試験を実施した積層ゴムは, フランジ組立型の高減 衰積層コムの縮小試験体である。積層ゴムの鈶直方向復元力特性 が, 積層ゴムのサイズ, フランジ構造, ゴム材料の違いによってど の程度影響を受けるかについては，今後の検討課題となる。した がって, 多種多様な積層ゴムの鈶直載荷試験を実施して試験データ を蓄積することで, 積層ゴム種別毎の鈶直方向復元力特性の把握, ならびに復元カモデルの適正パラメータについて検討を継続する必 要がある。

\section{参考文献}

1) 田中 洋・加藤広宣・跡部義久：免震建物の性能評定シートの分析（その 1,2 ），日本建築学会大会学術講演梗概集，581-584，1997.

2）藤田 聡・鈴木重信・芳沢利和：建物免震用の積層ゴムに関する実験的研 究（第 3 報，100卜ン用積層ゴムの破断実験），日本機会学会論文集（C 編），54巻507号. 2618-2623，1988.

3）大鳥靖樹・松田泰治・石田勝彦：鉆入り積層ゴムの力学特性におよほす載 荷速度の影警について, 構造工学論文集, Vol.40B, 167-175, 1994.

4）大鳥靖樹・松田泰治・石田勝彦：高减衰積層ゴムの力学特性におよぼす載 荷速度の影響評価と要素設計への適用. 日本建築学会構造系論文集, 第466 号, 49-58, 1994.

5）高山峯夫：免霞構造用天然ゴム系積層ゴムアイソレータの限界性能, 日本 建築学会技術報告集，第 1 号，160-165，1995.

6）西尾浩治・松林裕一・石原哲哉・藤波健剛・柳沢延房：免震装置の引張特 性に関する研究（その 2)，日本建筑学会大会学術講演梗既集. 529-530, 1997 .

7) 大鳥靖樹 : 積層ゴム免霞要素の引張許容応力設定に関する検討, 日本建築 学会大会学術講演梗概集, 535-536, 1997.

8）田島 淳・深澤協三・望月満伸・立花正彦：引張及び引張・せん断を受け る高滅衰積層コムの力学的性状に関する実験的研究，構造工学論文集. Vol.44B, 223-230, 1998.

9）坂口 達・河島庸一・山田親文・菊地 優 - 北村佳久 - 林 章二: 引張力 を受ける積層ゴムの復元力特性に関する研究（その $1 \sim 3)$ ．日本建築学 会大会学術講演梗概集, 549-554, 1998.

10) 菊地 優：積層ゴムの鉊直方向復元力モデルに関する研究, 日本建築学会 大会学術講演梗概集. 561-562, 1998.

11) 日本免震構造協会編：免震積層ゴム入門，オーム社, 44-45, 1997.

12) ABAQUS Theory Manual \& User Manual. Ver5.7. Hibbitt Karlsson \& Sorensen Inc., 1997.

13) 日本建筑学会 : 免震構造設計指針, 丸善, 1993.

14) 藤田隆史・藤田 聡・鈴木重信・芳沢利和：建物免震用の積層ゴムに関す る実験的研究（第 2 報, 100 卜ン用積層ゴムの静的加力実験），日本機会学 会論文集（C編），53巻485号.71-81, 1987.

15) 高山峯夫・多田英之・吉田献一・和田 章 : Isolatorの有限要素解析 (そ の 5 ) せん断圧縮載荷解析について. 日本建築学会大会学術講演梗概集. 589-590, 1991.

16) 菊地 優・田村和夫・北村佳久：積層ゴムに引張力が作用する免震建物の 地震応答解析, 第10回日本地震工学シンポジウム論文集, 235-240, 1998

(1998年 9 月 1 日原稿受理, 1999年 5 月 24 日採用決定) 